$\left[\begin{array}{c}\text { Jpn. J. Hosp. Pharm. } \\ \text { 料 } \\ \text { 凟 } \\ 18(6)\end{array}\right]$

\title{
病院薬局研修生の調剂実地研修に関する考察
}

小川賀偉*, 門林宗男, 門脇裕子, 大石雅子, 鈴木芳郎, 矢内原千鶴子 大阪大学医学部附属病院薬剂部门

\section{Education Program of Hospital Pharmacy Practice for Resident Pharmacists}

\author{
Yoshinide Ogawa $\dagger$, Muneo Kadobayashi, Hiroko Kadowaki, \\ Masako Oishi, Yoshio Suzuki, Chizuko Yanaihara \\ Department of Pharmacy, Osaka University Hospital†
}

(Received May 15, 1992

(Accepted October 9, 1992)

\begin{abstract}
A detailed analysis was performed on dispensing errors made by resident pharmacists in the initial step of practice training at the Osaka University Hospital Pharmacy during 1989. Based on the results, the education program was improved to prevent the dispensing errors as possible. The newly established program was effectively applied to the education of resident pharmacists in the pharmacy in the following year 1990: the dispensing errors $16.9 \%$ during the first week in 1989 was reduced to $10.9 \%$ in 1990 .
\end{abstract}

Keywords— - hospital pharmacy practice; education program; dispensing; resident pharmacist

\section{は じめに}

病院薬剤師教育の一つとして医療機関, 特に大 学附属病院の薬剂部に扮いて, 病院研修生制度あ るいは薬剤部研修生制度が実施されている。当薬 剂部では, 大阪大学医学部附属病院研修生受け入 れ規定に則り毎年約35名の研修生を受け入れ，原 則として 6 カ月間独自の研修プログラムにより， 将来, 病院診療所勤務を目指す薬剤師のための卒 後研修教育を行ってきた，その研修プログラムの なかでも特に調剤実地研修（以下, 調剂研修と略 す）はとの基本となるものであり，実際の処方せ ん調剤を経験させることから, 正確性, 安全性に

$\dagger$ 大阪市福島区福島1-1-50；1-1-50, Fukushima， Fukushima-ku, Osaka, 553 Japan
ついて十分に配慮すると共に，研修教育の効果に ついても常に関心を寄せてきた．研修生制度は受 入れ施設によって異なるため, その内容を一概に 比較することは困難であるが，調剤研修に和ける 安全対策は共通の課題といえる. しかしながら, こうした研修生制度のみならず薬学系学生を対象 とした病院実習制度も含めて, 調剤研修の実態並 びに安全対策に関する報告は極めて少ない, ${ }^{1,2)}$. 当 薬剂部では，1989年度研修生の研修期間中に監査 担当者によって指摘された調剂上の過ちの特性を 分析し, 研修プログラムの改善と過ちの防止策に ついて検討した．また，その結果を1990年度の研 修プログラムに反映させ前年度と比較検討した. さらに, 両年度の研修生に研修についてのアンヶ ート調査を行った. 
本報ではこれらの結果を調剤研修の実態報告お よび安全対策への一考察として報告する。なお， 研修生は1989年度34名, 1990年度32名で両年度に おける研修生の平均的資質については大きな差は ないものとした.

\section{1. 研修プログラム}

当薬剤部研修プログラムの当初 3 カ月間の各室
における研修期間を表 1 に示した。研修生の各室 への配属は全研修生を二分し半数は調剂室に, 他 は $4 \sim 5$ 人の班単位とし, 各室をローテーション させる.4 月目からは, あらためて班別に 1 カ 月単位で各室の研修を行う. 研修当初 3 カ月間に おける実質研修日数は，調剂室が26日間で約50\% を占めている. 表 2 は研修開始後 3 力月間の講義 内容を示したものである. 調剤関連講義は28講

表 1. 研修プログラム（各室研修期間）

\begin{tabular}{|c|c|c|c|}
\hline 配 属 & 期 間（日数） & 配 属 & 期 間（日数） \\
\hline 調㨈室 & 26 & 薬品情報室 & 6 \\
\hline 製㨈室 & 6 & 試験室 & 3 \\
\hline 注射剤室 & 6 & 薬品管理室 & 3 \\
\hline
\end{tabular}

（当初 3 か月間）

表 2. 研修プログラム（講義内容）

\begin{tabular}{|c|c|c|c|c|c|}
\hline 内 容 & 講義数 & 時間 & 内 & 講笌数 & 時間 \\
\hline オリェンテーション & 1 & 1.5 & 病棟業務 & 1 & 1.5 \\
\hline 病院薬刘師倫理 & 2 & 3 & 服薬指導 & 2 & 3 \\
\hline 病院薬剂部組樴・運営 & 3 & 4.5 & $\mathrm{IVH}$ & 4 & 6 \\
\hline 調剤関連（麻薬を含む） & 28 & 42 & TDM & 1 & 1.5 \\
\hline 製浏業務 & 2 & 3 & 医薬品概論 & 7 & 10.5 \\
\hline 薬品情報 & 1 & 1.5 & 薬物療法（院内医師） & 4 & 6 \\
\hline 薬品管理 & 1 & 1.5 & 社会保険関連 & 2 & 3 \\
\hline 薬品試験 & 1 & 1.5 & コンピューター & 1 & 1.5 \\
\hline 研究活動 & 1 & 1.5 & その他 & 3 & 4.5 \\
\hline
\end{tabular}

（当初 3 か月間） 
表 3. 調剤研修上の過ち発生率 (1989年度)

\begin{tabular}{|c|c|c|c|c|c|c|c|}
\hline 項目 \週 & 第 1 週 & 第 13 週 & 第 25 週 & 項目 \週 & 第 1 週 & 第13 週 & 第25 週 \\
\hline 品 目 & 2.1 & 0.6 & 0.3 & 剂 形 & 0.6 & 0.0 & 0.0 \\
\hline 単 位 & 1.1 & 0.4 & 0.3 & 注 意 畫 & 1.2 & 0.2 & 0.4 \\
\hline 過 不 足 & 5.3 & 1.7 & 1.1 & 書＼cjkstart記 & 1.1 & 0.3 & 0.3 \\
\hline 玉V・重 複 & 0.2 & 0.1 & 0.0 & 調 剂 印 & 1.2 & 0.3 & 0.0 \\
\hline 内 袋 & 1.4 & 0.7 & 0.3 & 分包忡誤り & 0.1 & 0.0 & 0.0 \\
\hline 袋 入 遠 & 0.3 & 0.2 & 0.2 & 内規 遧反 & 2.5 & 0.2 & 0.2 \\
\hline & & & & 合 計 & $16.9 \%$ & $4.6 \%$ & $3.1 \%$ \\
\hline
\end{tabular}

義, 延べ42時間であり，これは講義全体の約 $43 \%$ にあたる、調剤室研修期間中はこの関連講義と平 行して調剂研修を行う.

\section{1989年度の調剤研修上の過ち分析}

1989年度研修生の調剂研修中, 監査担当者が指 摘した調剤上の過ち件数を処理処方せん枚数で除 して求めた過ち発生率を, 分類毎に研修開始後第 1 週, 第 13 週, 第25週について集計した結果が表 3 である. 研修生処理処方せ ん 枚 数は, 第 1 週 1180枚, 第13週2098枚, 第25週2529枚で集計の対 象は, いわゆる計数調剤のみに限定した. 調剤上 の過ち発生率は経時的に減少しており, 第 1 週で は $16.9 \%$, 第13週 $4.6 \%$, 研修終了時の第 25 週は $3.1 \%$ であった.この集計結果より, 研修中の過 誤対策として講義および調剤研修方法を検討し た.

3. 調剤関連講義の組み替えおよび自己記入式 チェックシートの導入

1989年度は調剂関連講義を処方せんの流れに応 じた順序で行い, 調剤研修も比較的早い段階で平 行して開始したが，このことが調剤内規未習熟に 伴ら調剤上の過ちにつながっているものと考えら れた。 そこで1990年度では調剤関連講義を組み替
え，早い段階で調剤過誤に関する講義を行い，過 誤防止の重要性を認識させるようにした。また， 処方せん監査の講義を独立して行い, 特に処方せ んチェックの観点について講義した. 図1は, 両 年度の調剂関連講義および調剂研修の流れを模式 的に示したものである. 一方, 過誤対策を考慮し た調剂研修方法として, 四 2 に示した自己記入式 チェックシートを作成し，1990年度の調剤研修時 は常時携帯させた。これは調剂上の過ちが生じた 場合, 監査担当者が過ちの種類を指摘し, 正・誤 欄にはそれぞれの具体的な商品名を，コメント欄 にはそのときの状況や原因・理由を自己記入させ る記録簿である。

\section{1990年度の調剤研修時の過ちの分析}

調剂関連講義を組み替え, 自己記入式チェック シートを活用して調剤研修を行った，1990年度研 修生の調剂上の過ち発生率の集計結果を表 4 亿示 した. 研修生処理処方せん枚数は, 第 1 週 1370 . 枚, 第13週2214枚, 第25週1448枚で, 過ち発生率 は第 1 週 $10.9 \%$ ，第13週 $2.8 \%$ ，第 25 週には $2.7 \%$. となり，1989年度より改善されていた。

\section{5. 過誤対策の評価}

表 3 , 表 4 により両年度の第 1 週と第 13 週の過 


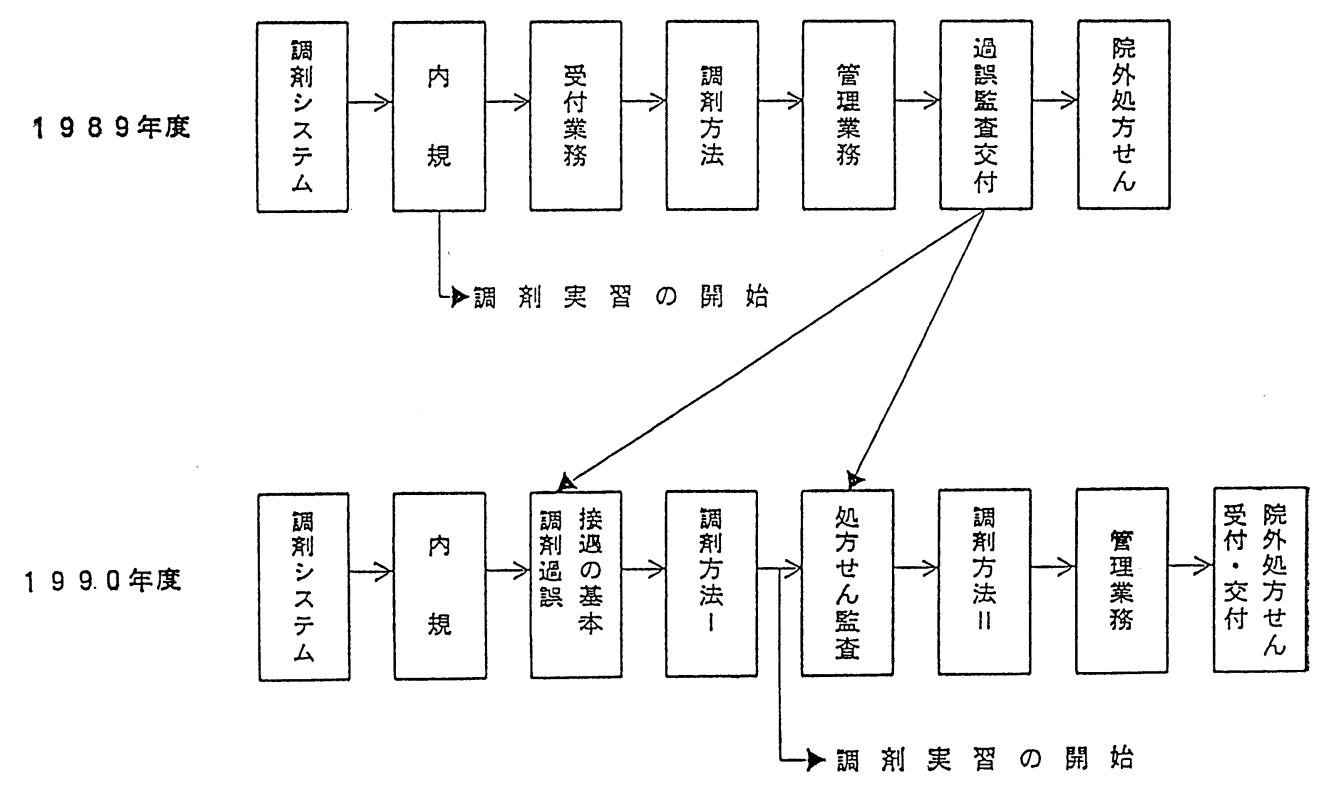

図 1. 調剂関連講義の組替え

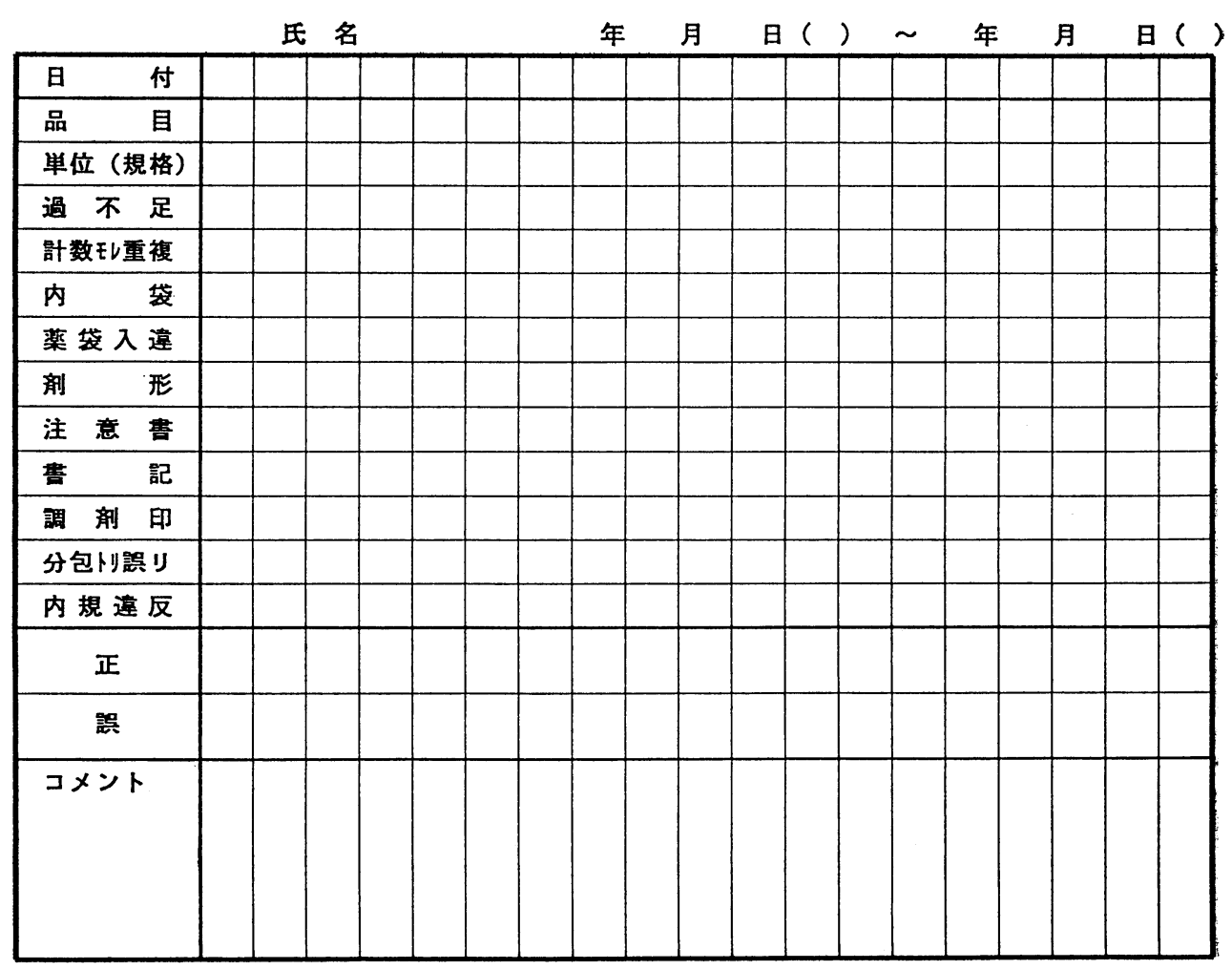

図 2. チェックシート 
表 4. 調剤研修上の過ち発生率（1990年度）

\begin{tabular}{|c|c|c|c|c|c|c|c|}
\hline 項目 \週 & 第 1 週 & 第 13 週 & 第 25 週 & 項目 \週 & 第 1 週 & 第 13 调 & 第25 週 \\
\hline 品 目 & 1.2 & 0.5 & 0.4 & 剂 形 & 0.7 & 0.0 & 0.1 \\
\hline 単 位 & 0.8 & 0.2 & 0.4 & 注 意 書 & 0.8 & 0.1 & 0.1 \\
\hline 過 不 足 & 3.1 & 0.7 & 1.0 & 書 記 & 0.4 & 0.1 & 0.1 \\
\hline 玉レ・重 複 & 0.1 & 0.1 & 0.1 & 調 剂 印 & 0.7 & 0.2 & 0.1 \\
\hline 内 茷 & 1.8 & 0.2 & 0.2 & 分包忓誤リ & 0.2 & 0.0 & 0.0 \\
\hline 袋 入 違 & 0.5 & 0.1 & 0.1 & 内規 遧反 & 0.5 & 0.3 & 0.1 \\
\hline & & & & 合 計 & $10.9 \%$ & $2.8 \%$ & $2.7 \%$ \\
\hline
\end{tabular}

ち発生率を比較すると, 第 1 週では, 1989 年度は 全体で $16.9 \%$ に何らかの調剤上の過ちがあった が，1990年度では10.9\%と減少しており， t 検定 では明らかな有意差が見られた。項目別では，内 規違反，薬剤数の過不足などが減少したが，薬袋 作製に関する過ちには余り変化がみられなかっ た. 第13週の比較では，1989年度は全体で4.6\%， 1990年度は $2.8 \%$ と減少しているが有意差はなか った。このことから，今回試みた調剤過誤対策を 重視した講義への組み替え, 並びに自己記入式チ ェックシートの導入は, 調剤研修開始初期の習熟 度向上につながったものと考えられる。

\section{6. 研修生へのアンケート調査の結果}

研修を受ける側の研修生が現在の研修制度をど のように感じているかを知る目的で, 両年度研修 生にアンケート調査を行った。その設問と回答集 計結果を図 3 , 図 4 に示したが，各設問への回答 をまとめると次のようになる。

1-1）調剤研修時間について, 約70\%が適当と 回答し，約 $20 \%$ が増加を希望した.

1-2）調剂研修内容について，不満足やその他 の意見の中には，散剤や水剂調剂などいわゆる計 量調剤の研修機会の増加を希望しているものもあ
った。

2-1）調剂関連講義内容について，約 $80 \%$ が適 当であると回答したが，処方解析などの講義を希 望する意見もあった。

2-2）調剤関連講義と実地研修の順序につい て, 講義の先行を望む割合が多く今回の試みの妥 当性を裏付ける結果となった。

3. 研修期間については， 6 カ月間を希望する 割合が圧倒的であった。

4. 学生病院実習との比較では, 当院研修生の 約 $90 \%$ 学生病院実習を経験しているが，学生病 院実習だけでよかったと回答したものはなかっ た. 約25\%が研修だけでよいとし，約60\%は学生 病院実習, 研修とも必要であると回答した.

5. 研修に対する評価では，両年度とも $20 \%$ の 積極的評価を含めて $90 \%$ 以上が役立っていると評 価した。

$$
\text { まとめ }
$$

当院薬剂部研修生における調剂実地研修の実態 調査を行い, 調剤上の過ちの特性を明らかにし た. また，その資料を解析し過誤防止対策につい て検討を行った結果, 調剂過誤防止対策を重視し 
1. 調剤研悠について

1）研修時間は

(1)增やしてほしかった。

(2)減らしてほしかった。

(3)適当であった。

(4) その他 (

2) 研修内容は

(1)適当であった。

(2) 不満足であった。

(3) その他 (

2. 研悠中の講義カリキュラムの

1) 調郕関連講義の内容について

(1) 適当であった。

(2) 不満であった。

(3) その他 (

2）調剤関連講義と調郕研修の順序について

(1)調剤関連講義を先にするほうが良い。

(2) 調戍研修を先にするほうが良い。

(3) どちらともいえない。

3. あなたの経験から研修期間として何か月ぐらいが適当と考えますか。

(1) 3 か月

(2) 6 か月

(3) 12 月

(4) その他 ( )

4. 学生実習での経験と、研修での経験を比較すると、

(1) 学生実習だけで十分である。

(2)研修だけで十分である。

(3) どちらも必要である。

(4) どちらも必要ない。

(5) その他 (

5. あなたにとって研修が現在の職場で役立っていますか。

(1) とても役立っている。

(2) 役立っている。

(3) 役立っていない。

(4) どちらともいえない。

困 3. 研修に関するアンケート調査の設問

た研修プログラムへの組み替えと自己記入式チェ ックシート方式の導入が研修初期の調剂習熟度向 上に寄与できたと評価している. 薬学教育協議会 による「薬学教育と薬剤師教育に関する専門委員

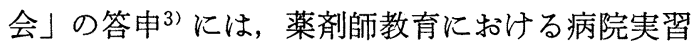
の必要性が盛り込まれているが, 安全で効果的な
病院実習を行うにあたっては，適正な基準による 教育プログラムの構築と実習体制の整備が不可欠 であることが本調査でも明らかとなった。一方， 今回のアンケート調査より, 将来病院薬剤師を目 指寸薬剤師には, 研修制度の必要性が十分認識さ れていることがわかった。 今後とも，病院薬局で 


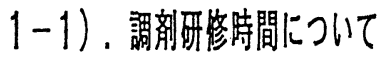

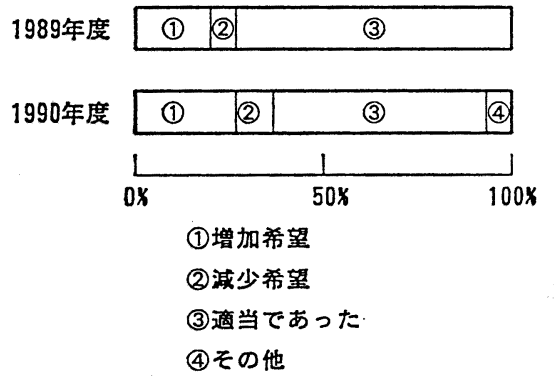

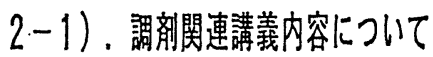

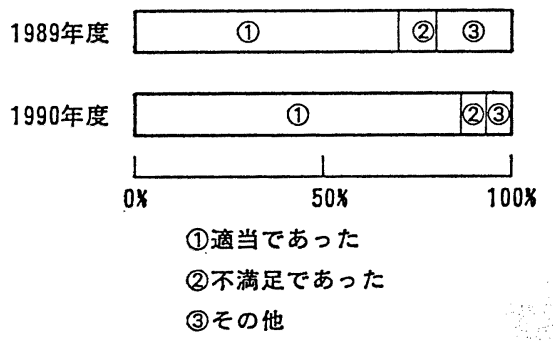

3. 希望する可整期間ついて

1989年度 (1) (2) 3(4)

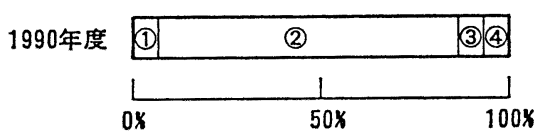

(1) 3 か月

(2) 6 か月

(3) 12 か月

(4) の他

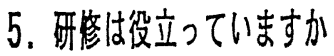

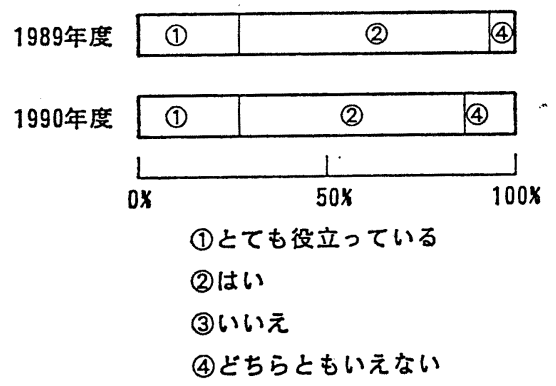

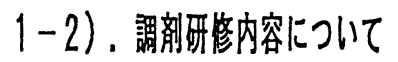

1989年度

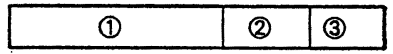

1990年度

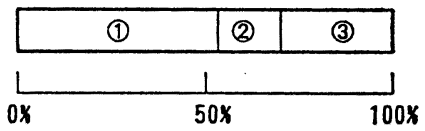

(1)適当であった

(2)不渾足であった

(3) の他

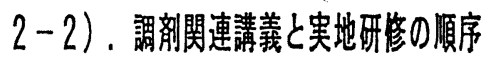

1989年度

\begin{tabular}{|l|l|l|}
\hline (1) & (2) & (3) \\
\hline
\end{tabular}

1990年度

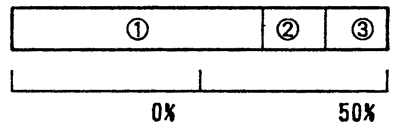

(1)潇转先行が䍿ましい

(2)実地研袋先行が望ましい

(3)どちらともいえない

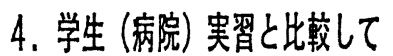

1989年度

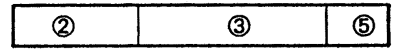

1990年度

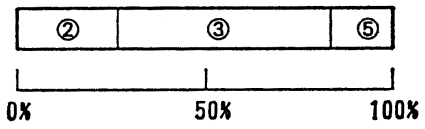

(1)学生 (病院) 実習だけでよい

(2)研管だけでよい

(3)雨方必要である

(4)どちらも不必要である

(5) の他

図 4. 研修についてのアンケート調査結果

の研修が生涯の職能を支える大きな礎となるよう 充実させることはもちろん，安全性を考慮した研
修制度の確立へ努力し，われわれの責務を果たし て行かねばならないと考えている. 


\section{引用文献}

1）古川裕之, 平戸久美子, 古瀬 裕, 旭満里子, 横 川弘一, 島貫喜一, 田村裕喜男, 中野 修, 打和 寿子, 中島恵美, 市村藤雄, 病院薬学, 16, 397404 (1990).
2) 旭満理子, 松下 良, 田村裕喜男, 横川弘一, 中 野修, 打和寿子, 島貫喜一, 古川裕之, 中島恵美, 市村藤雄, 病院薬学, 17, 65-76 (1991).

3）薬学教育協議会「薬学教育々薬剤師教育に関する 専門委員会」答申, 1988年 7 月. 